\title{
PENERAPAN STRATEGI PROCESS ORIENTED GUIDED INQUIRY LEARNING (POGIL) UNTUK MENINGKATKAN PRESTASI BELAJAR SISWA
}

\author{
Nia Junita Yusuf *, Herdini, Radjawali Usman Rery \\ Program Studi Pendidikan Kimia, Fakultas Keguruan dan Ilmu Pendidikan Universitas Riau, \\ Kampus Binawidya KM 12,5, Pekanbaru 28293, Riau, Indonesia
}

\begin{tabular}{l}
\hline \multicolumn{1}{c}{ Informasi Artikel } \\
\hline Sejarah Artikel: \\
Diterima 30 Maret 2019 \\
Disetujui 23 Juli 2019 \\
Dipublikasikan 25 Juli 2019 \\
\hline Keywords: \\
Hydrocarbon Compounds, \\
Learning Achievement, \\
Process Oriented Guided \\
Inquiry Learning (POGIL) \\
Strategy \\
\hline
\end{tabular}

\begin{abstract}
Abstrak
Penelitian ini bertujuan untuk mengetahui peningkatan prestasi belajar peserta didik dengan penerapan strategi process oriented guided inquiry learning (POGIL) pada pokok bahasan senyawa hidrokarbon. Penelitian ini dijalankan di kelas XI SMA Negeri 10 Pekanbaru. Metode penelitian yang digunakan adalah eksperimen dengan desain penelitian randomized control group pretest-posttest. Instrumen penelitian berupa soal pilihan ganda materi senyawa hidrokarbon yang telah diuji validitas dan reliabilitasnya $(r=0,953)$. Sampel dalam penelitian ini terdiri atas kelas eksperimen $(\mathrm{n}=36)$ dan kelas kontrol $(\mathrm{n}=35)$ sebagai kelas kontrol. Kelompok eksperimen diberi perlakuan dengan penerapan strategi POGIL, sedangkan kelompok kontrol tanpa penerapan strategi POGIL. Analisa data dilakukan menggunakan uji-t pihak kanan. Berdasarkan hasil analisis data diperoleh $t_{\text {hitung }}>t_{\text {tabel }}(3,07>1,67)$ dengan $\alpha=0,05$, dk $=69$ sehingga dapat disimpulkan bahwa penerapan strategi POGIL dapat meningkatkan prestasi belajar peserta didik pada pokok bahasan senyawa hidrokarbon.
\end{abstract}

\begin{abstract}
This research aimed to increase students achievement implementation of process oriented guided inquiry learning (POGIL) strategy on subject hydrocarbon compounds. This research was conducted at class X1, Senior High School stated 10 Pekanbaru. The type of this research is experimental research with randomized control group pretest-posttest design Instrument in this research is multiple choice question of hydrocarbon compounds that has been test validation and reliability $(r=0,953)$. Subject of this research are experimental class $(n=36)$ and control class $(n=35)$. The experimental group was treated with implementation of POGIL while the control group without implementation of POGIL. The data analysis was using t-test right side. Based on the data analysis, it is obtained that $t_{\text {count }}>t_{\text {table }}$ $(3,07>1,67)$ with $\alpha=0,05, d k=69$, so it can be concluded that the implementation POGIL can improve students achievement on the subject hydrocarbon compounds.
\end{abstract}

(C) 2019 Universitas Riau

*Alamat korespondensi:

niajunita21@gmail.com (NJY)

No. Telf: 081275087410 


\section{Jurnal Pendidikan Kimia Universitas Riau 2019 4(2): 17-26}

https://ejournal.unri.ac.id/index.php/JPKUR

\section{PENDAHULUAN}

Berdasarkan hasil wawancara dengan salah seorang guru kimia kelas XI SMA Negeri di Pekanbaru diperoleh informasi bahwa masih banyak peserta didik yang hasil belajar pada pokok bahasan senyawa hidrokarbon tahun ajaran 2016/2017 tidak memenuhi Kriteria Ketuntasan Minimum (KKM) yang ditetapkan yaitu 78. Pencapaian ketuntasan yang kurang maksimal tersebut disebabkan karena peserta didik yang kurang memahami konsep dalam subpokok bahasan membuat rumus struktur, memberi nama senyawa, membuat isomer, dan menentukan reaksi. Peserta didik kurang memahami konsep disebabkan karena peserta didik kurang terlibat aktif dalam membangun atau membentuk konsep serta kurangnya rasa percaya diri peserta didik ketika mengikuti proses pembelajaran. Proses pembelajaran yang diselenggarakan oleh guru sebenarnya sudah berlangsung dengan baik, tetapi peserta didik masih belum mampu mendorong siswa agar terlibat aktif dalam mengkonstruksi atau membangun konsep-konsep yang dipelajari. Akibatnya peserta didik tidak terlalu memahami materi pembelajaran, terlihat dari kurangnya percaya diri siswa untuk bertanya maupun mengerjakan soal latihan selama proses pembelajaran.

Senyawa hidrokarbon merupakan salah satu pokok bahasan yang bersifat konseptual dan memerlukan pemahaman. Oleh sebab itu, apabila peserta didik tidak mampu terlibat secara langsung dalam proses pembelajaran dikhawatirkan peserta didik cenderung hanya menghafal tanpa memahami dan mengaplikasikan konsep yang akhirnya dapat berpengaruh terhadap prestasi belajar peserta didik. Menyikapi permasalahan tersebut, diperlukan strategi yang dapat melibatkan siswa secara aktif selama pembelajaran untuk meningkatkan prestasi belajar peserta didik. Penggunaan strategi pembelajaran yang tepat diharapkan mampu meningkatkan prestasi belajar peserta didik.

Salah satu strategi pembelajaran yang mampu melibatkan siswa secara aktif adalah Process Oriented Guided Inquiry Learning (POGIL). Strategi POGIL merupakan pembelajaran inkuiri terbimbing yang berorientasi pada proses dan berpusat pada peserta didik dalam suatu pembelajaran aktif yang menggunakan kelompok belajar, aktivitas guided inquiry untuk mengembangkan pengetahuan, pertanyaan untuk meningkatkan kemampuan berfikir, memecahkan masalah, metakognisi, dan tanggung jawab individu (Hanson, 2006). Tahapan pembelajaran POGIL terdiri dari 3 tahapan yaitu eksplorasi, penemuan konsep dan aplikasi (Warsono dan Haryanto, 2013). Melalui siklus belajar dalam kegiatan inkuiri terbimbing, strategi POGIL membantu peserta didik mengembangkan. Selama penerapan strategi POGIL akan terjadi proses pemerolehan informasi, analisis situasi terhadap informasi, dan pengetahuan awal untuk memperoleh konsep yang tepat secara keilmuan. Tujuan dari POGIL adalah untuk melibatkan peserta didik dalam proses pembelajaran dan membantu peserta didik menguasai materi melalui pemahaman konseptual serta pengembangan kemampuan belajar esensial daripada belajar dengan cara mengingat dan menghapal (Sulalah \& Suyuno, 2014).

Strategi POGIL membantu peserta didik untuk memahami konsep materi secara mendalam. Hal ini disebabkan oleh beberapa karakteristik yang dimiliki oleh model pembelajaran POGIL yaitu: 1) implementasi POGIL menuntut siswa untuk bekerja sama 


\section{Jurnal Pendidikan Kimia Universitas Riau 2019 4(2): 17-26}

https://ejournal.unri.ac.id/index.php/JPKUR

dalam proses pembelajaran, 2) siswa beraktivitas dalam kegiatan pembelajaran dengan didampingi guru yang berperan sebagai fasilitator, dan 3) siswa selalu dibimbing dengan pertanyaan berpikir kritis yang disusun secara sistematis (Chase, dkk., 2013). Berdasarkan latar belakang di atas, POGIL diketahui dapat membantu penguasaan dan pemahaman konsep peserta didik karena melibatkan peserta didik secara aktif selama proses belajar sehingga prestasi belajar peserta didik meningkat. Oleh sebab itu, penelitian ini dilaksanakan dengan tujuan untuk mengetahui apakah penerapan strategi POGIL dapat meningkatkan prestasi belajar peserta didik pada pokok bahasan Senyawa Hidrokarbon. Strategi POGIL diharapkan dapat meningkatkan prestasi belajar peserta didik pada pokok bahasan senyawa hidrokarbon dan diharapkan dapat menjadi bahan pertimbangan guru sebagai salah satu alternatif strategi pembelajaran kimia di sekolah.

\section{METODE PENELITIAN}

Penelitian pengembangan bahan ajar dalam bentuk buku saku pada pokok bahasan asam basa Penelitian ini merupakan penelitian eksperimen dengan rancangan penelitian penelitian Randomized Control Group Pretest-Posttest. Penelitian ini dilaksanakan di kelas XI SMA Negeri 10 Pekanbaru. Sampel penelitian terdiri atas dua kelas, yaitu kelas eksperimen $(n=36)$ dan kelas kontrol $(n=35)$ yang dipilih secara acak. Kelas eksperimen melaksanakan pembelajaran dengan menerapkan strategi POGIL, sedangkan kelas kontrol tanpa penerapan strategi POGIL. Tahapan pembelajaran dengan strategi POGIL disajikan dalam Tabel 1.

Tabel 1. Tahapan Pembelajaran dengan Strategi POGIL

\section{Kegiatan A wal}

1. Guru membuka pembelajaran dengan salam kepada peserta didik

2. Guru menciptakan suasana kelas yang religius dengan menunjuk ketua kelas untuk memimpin doa, memeriksa kehadiran peserta didik, kebersihan dan kerapian kelas sebagai wujud kepedulian lingkungan.

3. Guru memberikan apersepsi dan motivasi kepada peserta didik.

4. Guru menyampaikan tujuan pembelajaran.

\section{Kegiatan Inti}

1. Peserta didik diminta duduk di dalam kelompok yang terdiri 4 orang dengan masing-masing memiliki tugas yang berbeda (manager, spokesperson, recorder, dan strategy analyst). Pada pertemuan berikutnya ke empat tugas dilakukan rolling supaya masing-masing individu didalam kelompok mendapat tugas yang berbeda untuk setiap pertemuan.

\section{Tahap 1 : Eksplorasi \\ Mengamati}

2. Peserta didik dibimbing untuk mengembangkan pemahaman tentang konsep dengan berusaha memahami buku paket kimia mengenai pokok bahasan yang akan dipelajari.

3. Peserta didik yang dipimpin oleh manager bekerja sama membangun pengetahuan dasar tentang konsep dan memastikan anggota kelompok berpatisipasi dalam memahami pokok bahasan yang dipelajari. 


\section{Menanya}

4. Guru memberikan kesempatan kepada peserta didik untuk menanyakan hal yang belum dipahami. Jika peserta didik tidak bertanya, maka guru mengarahkan peserta didik untuk bertanya.

\section{Mengumpulkan data}

5. Guru membagikan LKPD.

6. Guru membimbing peserta didik untuk mengembangkan pemahamannya melalui menjawab pertanyaan yang terdapat pada LKPD.

7. Peserta didik yang berperan sebagai strategy analyst dalam mengerjakan LKPD mencari sumber informasi yang relevan (melalui bahan ajar, buku kimia,dll) serta memeriksa dan menganalisis informasi yang didapatkan dengan penuh rasa tanggung jawab dan melaporkan ke anggota kelompok.

8. Peserta didik yang dipimpin oleh manager memastikan anggota kelompok berpatisipasi dalam menjawab lkpd pada pokok bahasan yang dipelajari.

\section{Mengasosiasi}

\section{Tahap 2 : Pembentukan Konsep}

9. Peserta didik dengan teliti menjawab soal bagian penemuan atau pembentukan konsep pada LKPD dengan penuh rasa tanggung jawab.

10. Guru memberikan bimbingan kepada setiap kelompok dalam menjawab latihan yang diberikan.

\section{Tahap 3 : Aplikasi}

11. Peserta didik menerapkan konsep yang diperoleh untuk mengerjakan soal yang diberikan pada bagian tahap aplikasi konsep.

12. Guru membimbing peserta didik dalam penerapan konsep dan latihan soal.

13. Peserta didik yang berperan sebagai recorder membantu mencatat hasil pengamatan dan jawaban pertanyaan pada LKPD

\section{Mengkomunikasikan}

14. Guru menunjuk salah satu kelompok untuk mempresentasikan hasil diskusi kelompok. Peserta didik yang akan menyajikan hasil diskusi kelompok adalah peserta didik yang berperan sebagai spokesperson.

15. Guru memberikan kesempatan kepada kelompok lain untuk bertanya, memberikan pendapat atau sanggahan mengenai apa yang ditampilkan.

16. Guru memberikan penguatan serta meluruskan konsep yang belum sesuai dengan tujuan.

17. Guru meminta peserta didik mengumpulkan LKPD yang telah dikerjakan.

\section{Kegiatan Penutup}

1. Guru meminta peserta didik untuk menyimpulkan pembelajaran secara logis sekaligus memberi penguatan terhadap kesimpulan peserta didik.

2. Peserta didik mengerjakan evaluasi yang diberikan guru secara individu.

3. peserta didik diberikan tanggung jawab untuk mempelajari materi selanjutnya.

4. Guru menutup pelajaran dan mengucapkan salam.

Instrumen penelitian yang digunakan terdiri atas instrumen perlakuan dan instrumen pengukuran. Instrumen perlakuan berupa Rencana Pelaksanaan Pembelajaran (RPP) dan Lembar Kerja Peserta Didik (LKPD). Instrumen pengukuran digunakan untuk pengambilan data berupa soal pilihan ganda materi senyawa hidrokarbon $(\mathrm{r}=0,953)$. Data yang dikumpulkan dalam penelitian ini diperoleh dari: (1) Pretest yang diberikan di 


\section{Jurnal Pendidikan Kimia Universitas Riau 2019 4(2): 17-26}

https://ejournal.unri.ac.id/index.php/JPKUR

awal penelitian dan juga digunakan untuk mengetahui kemampuan awal peserta didik pada pokok bahasan senyawa hidrokarbon, (2) Posttest yang diberikan setelah seluruh proses pembelajaran selesai dilakukan.

Teknik analisis data yang digunakan adalah uji-t, dilakukan setelah data diuji normalitas dan homogenitasnya. Uji normalitas data dilakukan dengan menggunakan uji Lilliefors. Data berdistribusi normal jika Lmaks $\leq$ Ltabel dengan kriteria pengujian $(\alpha$ $=0,05)$. Harga Ltabel diperoleh dengan rumus:

$$
L_{\text {tabel }}=\frac{0,886}{\sqrt{n}}
$$

(Irianto, 2008)

Pengujian homogenitas varians dilakukan menggunakan uji $\mathrm{F}$ dengan rumus:

$$
F_{\text {hitung }}=\frac{\text { Varians Terbesar }}{\text { Varians Terkecil }}
$$

Kedua sampel mempunyai varians yang sama atau homogen jika $F_{\text {hitung }}<F_{\text {tabel }}$, dimana $F_{\text {tabel }}$ diperoleh dari daftar distribusi $F$ dengan peluang $\alpha$, dimana $(\alpha=0,05)$ dan $d k=\left(n_{1}-1, n_{2}-\right.$ 1). Kemudian dilanjutkan dengan uji kesamaan rata-rata menggunakan uji-t dua pihak untuk mengetahui kehomogenan kemampuan kedua sampel.

Untuk melihat perbedaan hasil belajar berupa prestasi belajar peserta didik antara kelas eksperimen dan kelas kontrol digunakan merupakan uji-t pihak kanan dengan rumusan sebagai berikut:

$$
\mathrm{t}=\frac{\bar{x}_{1}-\bar{x}_{2}}{S_{g} \sqrt{\frac{1}{n_{1}}+\frac{1}{n_{2}}}}
$$

Dengan Sg merupakan standar deviasi gabungan yang dapat dihitung menggunakan rumus:

$$
S_{g}^{2}=\frac{\left(n_{1}-1\right) S_{1}^{2}+\left(n_{2}-1\right) S_{2}^{2}}{n_{1}+n_{2}-2}
$$

Hipotesis diterima jika thitung $>$ tabel dengan kriteria probabilitas $1-\alpha$ dengan $\alpha$ $=0,05$ dan $\mathrm{dk}=\mathrm{n} 1+\mathrm{n} 2-2($ Sudjana, 2005).

\section{HASIL DAN PEMBAHASAN}

Data hasil pretest dan posttest peserta didik pada pokok bahasan senyawa hidrokarbon disajikan dalam Tabel 2. 
Jurnal Pendidikan Kimia Universitas Riau 2019 4(2): 17-26

https://ejournal.unri.ac.id/index.php/JPKUR

Tabel 2. Data Deskripsi Nilai Pretest-Posttest Kelas Eksperimen dan Kontrol

\begin{tabular}{crrrr}
\hline & Kelas & \multicolumn{2}{c}{ Eksperimen } & \multicolumn{2}{c}{ Kontrol } \\
\cline { 2 - 5 } & Pretest & Posttest & Pretest & Posttest \\
\hline Rata-rata & 23,264 & 86,111 & 23,286 & 80,071 \\
Standar deviasi & 5,727 & 6,747 & 6,691 & 6,345 \\
Nilai tertinggi & 35,000 & 95,000 & 37,500 & 95,000 \\
Nilai terendah & 12,500 & 70,000 & 12,500 & 70,000 \\
\hline
\end{tabular}

Berdasarkan paparan data pada Tabel 2, rata-rata nilai pretest kedua kelas tidak jauh berbeda yaitu 23,286 untuk kelas kontrol dan 23,264 untuk kelas eksperimen. Nilai posttest menunjukkan bahwa nilai terendah kelas kontrol dan kelas eksperimen adalah sama, yaitu 70. Nilai tertinggi posttest kelas kontrol dan kelas eksperimen juga sama, yaitu 95. Ratarata nilai posttest kelas eksperimen yaitu 86,111 lebih tinggi dari rata-rata nilai posttest pada kelas kontrol yaitu 80,071.

Pengujian hipotesis penelitian dilakukan dengan uji-t pihak kanan. Sebelum itu, dilakukan uji normalitas dan homogenitas terlebih dahulu terhadap data hasil pretest dan posttest peserta didik. Hasil uji normalitas disajikan dalam Tabel 3.

Tabel 3. Hasil Uji Normalitas

\begin{tabular}{ccccccc}
\hline Data & Kelas & $\boldsymbol{N}$ & $\overline{\boldsymbol{X}}$ & $\mathbf{S}$ & Lmaks & Ltabel \\
\hline Pretest & Eksperiman & 36 & 23,264 & 5,727 & 0,081 & 0,148 \\
& Kontrol & 35 & 23,286 & 6,691 & 0,145 & 0,150 \\
\multirow{2}{*}{ Posttest } & Eksperimen & 36 & 86,111 & 6,747 & 0,093 & 0,148 \\
& Kontrol & 35 & 80,071 & 6,344 & 0,133 & 0,150 \\
\hline
\end{tabular}

Berdasarkan analisis data pada Tabel 3 yang menunjukkan hasil uji normalitas data pretest dan posttest memiliki harga $\mathrm{L}_{\text {maksimum }} \leq \mathrm{L}_{\text {tabel }}$ sehingga dapat disimpulkan bahwa data berdistribusi normal. Selanjutnya hasil uji homogenitas data pretest disajikan dalam Tabel 4.

Tabel 4. Hasil Uji Homogenitas

\begin{tabular}{|c|c|c|c|c|}
\hline Kelas & $N$ & $\overline{\boldsymbol{X}}$ & $F_{\text {tabel }}$ & F $_{\text {hitung }}$ \\
\hline Eksperimen & 36 & 23,264 & \multirow{2}{*}{1,80} & \multirow{2}{*}{1,37} \\
\hline Kontrol & 35 & 23,286 & & \\
\hline
\end{tabular}

Berdasarkan hasil analisis yang dipaparkan dalam Tabel 4 terlihat bahwa hasil uji homogenitas memenuhi persyaratan $\mathrm{F}_{\text {hitung }} \leq \mathrm{F}_{\text {tabel }}$ sehingga dapat disimpulkan kedua kelas sampel penelitian memiliki varians yang sama dan memiliki kemampuan awal yang sama. Selanjutnya dilakukan pengujian hipotesis dengan menggunakan uji t-pihak kanan. Data yang digunakan untuk uji hipotesis dalam penelitian ini adalah selisih antara nilai posttest dan pretest. Hasil analisis uji hipotesis disajikan dalam Tabel 5. 
Jurnal Pendidikan Kimia Universitas Riau 2019 4(2): 17-26

https://ejournal.unri.ac.id/index.php/JPKUR

Tabel 5. Hasil Analisis Uji Hipotesis Penelitian

\begin{tabular}{cccccc}
\hline Kelas & $\boldsymbol{N}$ & $\begin{array}{c}\text { Nilai rata - rata selisih } \\
\text { pretest dan posttest }\end{array}$ & $\mathbf{S}_{\text {gab }}$ & $\mathbf{t}_{\text {tabel }}$ & thitung $^{\text {2 }}$ \\
\hline $\begin{array}{c}\text { Eksperimen } \\
\text { Kontrol }\end{array}$ & 36 & 62,847 & 8,316 & 1,670 & 3,070 \\
\hline
\end{tabular}

Berdasarkan hasil analisis uji hipotesis pada Tabel 5, terlihat bahwa thitung $>$ tabel yaitu 3,070 $>1,670$, dengan demikian hipotesis dapat diterima, artinya penerapan strategi Process Oriented Guided Inquiry Learning (POGIL) dapat meningkatkan prestasi belajar peserta didik pada pokok bahasan senyawa hidrokarbon. Penerapan strategi POGIL terbukti dapat meningkatkan prestasi belajar peserta didik karena proses pembelajaran pada strategi POGIL menggunakan kelompok belajar yang menjadikan peserta didik aktif dalam membangun pengetahuannya dan melatih keterampilan berpikir dalam menjawab pertanyaan yang diberikan pada setiap tahapan pada strategi POGIL. Strategi POGIL menggunakan kelompok belajar yang terdiri dari 4 peserta didik di dalam satu kelompok, di mana setiap anggota kelompok memiliki tugas masing-masing yang berbeda. Masingmasing anggota kelompok bertugas sebagai manager, strategy analyst, recorder, spokesperson. Kelompok belajar dalam penerapan strategi POGIL pada kelas eksperimen yang telah dilakukan terdiri dari 9 kelompok. Pembagian tugas kelompok yang dilakukan untuk memudahkan peserta didik untuk mengeksplorasi dalam menjawab pertanyaan, memudahkan peserta didik memahami konsep yang dibentuk dengan teman sekelompok sehingga pengetahuan peserta didik akan bertambah, selain itu juga agar lebih bertanggung jawab pada tugasnya masing-masing. Hal ini sesuai dengan pernyataan Sari, dkk. (2017) yang menyatakan bahwa pembelajaran POGIL akan memacu peserta didik untuk aktif berusaha menemukan konsep secara berkelompok, memadukan pemahaman lama dengan pengetahuan baru sehingga akan tercipta pembelajaran yang penuh makna yang akan memudahkan peserta didik memahami materi kimia.

Proses pembelajaran pada strategi POGIL dapat dilihat dalam tahap pembelajaran yang meliputi eksplorasi, penemuan konsep, dan aplikasi. Pada tahap eksplorasi, peserta didik mengembangkan pemahamannya mengenai pokok bahasan senyawa hidrokarbon dengan memahami buku paket kimia atau informasi lainnya. Peserta didik yang dipimpin oleh manager atau ketua kelompok saling bekerja sama untuk membangun pengetahuan dasar. Sebagai contoh pada pertemuan pertama peserta didik di dalam kelompoknya bersama-sama memahami subpokok bahasan jenis atom karbon dan guru memastikan kebenaran konsep dasar yang diperoleh peserta didik dengan memberi arahan dalam bentuk pertanyaan. Contoh guru bertanya "berdasarkan kemampuan untuk berikatan dengan atom karbon lainnya, atom karbon dalam suatu senyawa mempunyai kedudukan berbeda-beda, maka apa saja jenis dari atom karbon? Kemudian guru memfasilitasi peserta didik dengan membagikan LKPD untuk membangun pengetahuannya dengan menjawab serangkaian pertanyaan pada kegiatan 1 . Selanjutnya peserta didik yang berperan sebagai strategy analyst yang dibantu partisipasi anggota lainnya bersama-sama mencari dan 


\section{Jurnal Pendidikan Kimia Universitas Riau 2019 4(2): 17-26}

https://ejournal.unri.ac.id/index.php/JPKUR

mengumpulkan informasi dari berbagai sumber dalam menjawab pertanyaan yang diberikan untuk mengeksplorasi tugas yang harus diselesaikannya.

Adanya pertanyaan-pertanyaan pada tahap eksplorasi ini akan mendorong peserta didik untuk mencari sendiri jawaban dari pertanyaan yang ditanyakan sehingga peserta didik aktif dalam membangun pengetahuannya sendiri dan mengembangkan pemahaman sehingga pengetahuan yang diperolehnya lebih bermakna dan dapat bertahan dalam jangka yang panjang. Hal ini sesuai dengan pendapat Warsono dan Hariyanto (2013) yang menyatakan bahwa peserta didik mengembangkan pemahamannya tentang konsep dengan cara menanggapi serangkaian pertanyaan yang akan memandunya pada suatu proses untuk mengeksplorasi suatu model atau suatu tugas yang harus diselesaikannya. Menurut Hanson (2006), tujuan awal dari tahap eksplorasi adalah untuk memastikan bahwa peserta didik telah memiliki pengetahuan dasar yang mereka perlukan. Sehingga peserta didik lebih mudah memahami materi yang akan dipelajari.

Tahap penemuan konsep atau pembentukan konsep merupakan hasil dari tahap eksplorasi. Pada tahapan ini, konsep dibentuk dan diperkenalkan. Guru memperkenalkan suatu konsep dengan memberi contoh soal, kemudian peserta didik dipandu untuk berpikir berkaitan dengan pengetahuan dasar yang sudah diperolehnya dari tahap eksplorasi dengan contoh soal yang diberikan. Sebagai contoh pada pertemuan pertama mengenai jenis atom karbon, guru memberikan contoh soal penentuan posisi atom karbon, maka guru mengarahkan kepada peserta didik untuk menentukan mana yang tergolong atom karbon primer, sekunder, tersier dan kuartener dari struktur yang sudah diketahui dipapan tulis, dimana peserta didik sendiri yang menjawab arahan dari contoh yang diberikan dengan berbekalan pengetahuan dasar yang sudah diperoleh dari tahap eksplorasi. Tujuan dari memberikan contoh soal pada tahap ini adalah untuk membantu peserta didik untuk mengidentifikasi konsep serta untuk mengetahui kebenaran konsep yang ditemukan oleh peserta didik terhadap materi yang dipelajari. Setelah konsep berhasil diidentifikasi dan dipahami kemudian guru mengarahkan dan membimbing peserta didik untuk mengolah informasi yang sudah diperoleh dengan melanjutkan tugas berupa menjawab pertanyaan pada LKPD kegiatan 2 dan peserta didik diajak untuk membuat kesimpulan berdasarkan konsep yang telah ditemukannya. Peserta didik yang berperan sebagai recorder bertugas menyiapkan kesimpulan dan menyiapkan hasil diskusi kelompok bersama anggota lainnya dan peserta didik yang berperan sebagai manager memastikan anggotanya memahami materi yang dipelajari dan memastikan setiap anggota kelompok berpatisipasi dalam menjawab LKPD.

Guru sebagai fasilitator dalam pembelajaran memberikan bantuan berupa petunjuk, arahan atau pertanyaan penuntun kepada peserta didik untuk memahami dan membentuk konsep yang sedang dipelajari dan peserta didik dipandu oleh guru dalam berdiskusi. Hal ini sesuai dengan pendapat Febrilla, dkk. (2017) yang menyatakan bahwa tahap pembentukan konsep merupakan hasil dari tahap eksplorasi, konsep dibentuk dan diperkenalkan. Tahap ini dilakukan dengan memberikan pertanyaan-pertanyaan yang mendorong peserta didik berpikir berkaitan dengan hasil eksplorasi. Pada tahap ini peserta didik juga membuat suatu hubungan antara pengetahuan lama dengan pengetahuan baru 


\section{Jurnal Pendidikan Kimia Universitas Riau 2019 4(2): 17-26}

https://ejournal.unri.ac.id/index.php/JPKUR

sehingga bisa membuat kesimpulan yang tepat dan membantu peserta didik dalam membangun pemahaman konsep yang sedang dipelajari.

Tahap akhir dari strategi POGIL yaitu tahap aplikasi. Pada tahap ini guru memandu peserta didik untuk menerapkan pengetahuan baru yang ditemukan untuk menjawab pertanyaan berupa soal-soal latihan yang berhubungan dengan konsep yang sudah dipelajari. Contohnya peserta didik pada tahap aplikasi melanjutkan untuk mengerjakan latihan dalam LKPD kegiatan 3 dengan soal menentukan jumlah atom karbon primer, sekunder, tersier dan kuartener. Tujuan memberi latihan adalah untuk memperkuat konsep yang sudah dipahami dan dibentuk pada tahap sebelumnya serta memberi kesempatan kepada peserta didik untuk lebih percaya diri dalam menjawab soal latihan. Peserta didik yang berperan sebagai recorder membantu mencatat hasil diskusi dan peserta didik yang akan menyajikan hasil diskusi adalah peserta didik yang berperan sebagai spokesperson. Pada tahap ini, juga melatih kemampuan berpikir peserta didik dalam menyelesaikan latihan. Hal ini sesuai dengan pendapat Warsono dan Hariyanto (2013) yang menyatakan bahwa pada tahap ini pembelajar menerapkan pengetahuan barunya dalam latihan sebagai pemecahan masalah. Latihan akan memberikan kesempatan kepada para pembelajar untuk membangun rasa percaya diri dalam situasi sederhana dalam konteks yang familiar.

Strategi POGIL memberikan pengaruh terhadap peningkatan prestasi belajar peserta didik kelas eksperimen karena strategi yang diterapkan menarik perhatian peserta didik. Interaksi aktif antara peserta didik dan guru lebih banyak terjadi dan peserta didik lebih aktif untuk menemukan konsep dan mengembangkan pemahaman konsep secara berkelompok sehingga menumbuhkan rasa percaya diri ketika mengikuti proses pembelajaran. Dampak dari hal tersebut adalah peningkatan prestasi belajar peserta didik. Hal ini sesuai dengan pernyataan Alamanda dan Novita (2015) yang menyebutkan bahwa pengalaman belajar dengan strategi POGIL dapat meningkatkan kepercayaan diri sekaligus membantu peserta didik untuk memahami dan mengingat lebih lama dengan memberi bimbingan yang cukup untuk memungkinkan kedalaman pembelajaran dan pemahaman peserta didik dan akan mempengaruhi hasil belajar peserta didik.

\section{KESIMPULAN DAN REKOMENDASI}

\subsection{Kesimpulan}

Berdasarkan hasil penelitian diperoleh nilai thitung $=3,07$ sedangkan $t_{\text {tabel }}$ yang diperoleh dengan $\alpha=0,05$ dan $\mathrm{dk}=69$ adalah 1,67 sehingga thitung $>t_{\text {tabel }}(3,07>1,67)$, maka dapat disimpulkan bahwa penerapan strategi Process Oriented Guided Inquiry Learning (POGIL) dapat meningkatkan prestasi belajar peserta didik pada pokok bahasan senyawa hidrokarbon.

\subsection{Rekomendasi}

Berdasarkan pembahasan dan kesimpulan yang telah dikemukakan pada penelitian ini, maka penerapan strategi POGIL dapat direkomendasikan untuk dijadikan salah satu 
alternatif strategi pembelajaran untuk meningkatkan prestasi belajar peserta didik khususnya pada pokok bahasan senyawa hidrokarbon.

\section{DAFTAR PUSTAKA}

Alamanda, V.D. \& Novita, D. 2015. Penerapan strategi POGIL untuk meningkatkan selfefficancy siswa pada materi ikatan kimia kelas X. Jurnal Pendidikan Kimia 4(1): 3440

Chase A, Pakhira D, Stains M. 2013. Implementing process-oriented, guided-inquiry learning for the first time: adaptations and shortterm impacts on students' attitude and performance. Journal Chemistry Education. 90: 409-416

Hanson, D.M. 2006. Instructor's Guide to Process Oriented Guided Inquiry Learning. Lisle. Pacific Crest. IL. New York.

Febrilla, P.R., Dasna, W.I., \& Sutrisno. 2017. Pengembangan Desain Pembelajaran Strategi POGIL untuk Meningkatkan Keterampilan Proses Sains Siswa pada Pokok Bahasan Reaksi Redoks. SN-KPK IX Kimia : 103:110. UM. Malang

Irianto, A. 2008. Statistika Konsep Dasar dan Aplikasi. Kencana. Jakarta

Sari, B.R., Duhartono, \& Darwis, D.. 2017. Pengaruh Penerapan Penalaran Berbasis Konsep Melalui Strategi Pembelajaran Process Oriented Guided Inquiry Learning (POGIL) terhadap Prestasi Belajar Siswa Pada Materi Redoks. Jurnal Riset Pensisikan Kimia 7(1):7-13

Sudjana. 2005. Metode Statistik. Tarsito. Bandung.

Sulalah, A. \& Suyuno. 2014. Implementasi Strategi POGIL untuk Mereduksi Miskonsepsi pada Materi Stoikiometri Kelas X di SMAN 1 Kandangan. Jurnal Pendidikan Kimia 3(3):187-192

Sundayana, R. 2015. Statistika Penelitian Pendidikan. Alfabeta. Bandung

Warsono \& Hariyanto. 2014. Pembelajaran Aktif (Teori dan Assesmen). Rosda. Surabaya 